\title{
Analysis of the Trading Regime of the Leather Value Chain Strata in Kenya
}

\author{
Mwinyikione Mwinyihija \\ Executive Director, Leather and Leather Products Institute (LLPI-COMESA), Addis \\ Ababa, Ethiopia
}

Tel: 251-930-077-660Ｅ-mail: mmwinyi@ gmail.com

Received: July 6, 2014 Accepted: July 22, $2014 \quad$ Published: August 30, 2014

doi:10.5296/bms.v5i2.5924 URL: http://dx.doi.org/10.5296/bms.v5i2.5924

\begin{abstract}
Trade in leather and leather products has progressively increased at the global arena. This growth has had much impact in the developing world mostly as the leather sector moved to Asia and projected to translate to Africa. Thus, the need to scrutinize the preparedness of the continent through the member-states is crucial. Therefore, the study attempted to analyse the trading regime of the leather value chain strata. A quantitative approach $(n=244)$, descriptive analysis including an aggregate score to ascertain the top activities impacting on trade regime in Kenya was carried out. The results were varied depending on the individual stratums where the lower strata of the chain (producers, butchers and traders) were found to concentrate mostly in domestic trade. The upper value chains strata were differently impacted with tanners active on domestic (raw material sourcing) and export (for the semi-processed leather) trade. In retrospect, Leathergoods and Footwear were engaged with domestic trade but had challenges on massive second hand and poor quality leather related imports. These imports at most affected their competitiveness and productivity denying the both the stratums accruable potential available in the country's leather sector. The overall results indicated that trade activities were significant $(\mathrm{p}<0.05)$ to the value chain stratum. This result was important as appropriate interventional measures would therefore go a long way in optimizing on trade related benefits to the socio-economic dimension of the country such as employment, wealth creation and rural development.
\end{abstract}

Keywords: Leather sector, Development in Africa, Competitiveness, Agro-based commodity, \& Value Addition 


\section{Introduction}

The leather sector's relevance to the developing world is becoming conspicuous in relation to the magnitude of trading activity observed in recent years. Africa has had its challenges but managed to escape some of the tumultuous upheavals that stirred the world economies around 2008/09 period (Mwinyihija and Quisenberry, 2013). In the developing world, Asia emerged the most successful with China and India leading the pack. Other countries with notable performance include Brazil with most of the European countries indicating a retreat on operations.

Of interest is that as most of the European enterprises downscale their operations in Europe, a major translocation of their leather processing ventures to Asia has been observed (Mwinyihija, 2014). However, countries such as China who received the highest translocated enterprises have started to experience impacts of high standards of living. This observation has resulted increased labour costs, shortage of workers and inefficient state corporations. For example, from a continental analysis, Asia leads in both consumption of leather products and the production of footwear with $83 \%$ of a total of 13 billion pairs of shoes (synthetic, leather and hybrid of the two) produced globally (FAO, 2011).Comparatively, Africa is at the bottom producing $1.3 \%$ surpassing only Oceania at $1.2 \%$ of the global production. According to Mwinyihija (2011) and FAO (2011) Africa's global share in the production of leather shoes is $3.8 \%(4,498.10$ million); Kenya is $2.40 \%$ of Africa's share and $0.09 \%$ of the global production. On exports Kenya has a global share of $0.02 \%$ valued at US\$ 78 million per annum. Thus, the importance of the leather sector as a livestock agro-based commodity is pertinent.

The leather industry being a livestock agro-based sector continues to be the engine of Kenya's economic growth with an estimated contribution of over 4\% of the Agricultural GDP. According to the economic survey of conducted by the Kenya National Bureau of Statistics (KNBS) there was indication that the livestock sector a major component of the agricultural sector, contributes $12 \%$ to the GDP with a share of $40 \%$ of the agric. GDP (KNBS, 2012). The same review reports that the livestock sector also represents $50 \%$ of the agricultural labour force and it is estimated that $70 \%$ of the livestock population supports 10 million people in this country.

The importance of the livestock sector and associated commodity based industries (including the leather sector) is immense as $80 \%$ of the country is arid and semi-arid. The socio economic dimensions of the livestock sector in Kenya (including Africa), therefore, supports employment, wealth creation, trade, household food security, nutrition, draught power, agro-based commodity development and manure (Mwinyihija, personal communication, June 17, 2014). In retrospect, appropriate value addition initiatives on agro-based commodities are required to optimize on the accruals of derived commodities (Sharma, Pathania, \& Lal, 2010). Value adding in agricultural commodities can be viewed as improving the natural and conventional form, quality and appeal of a product subsequently increasing the consumer valuation beginning from farm level to marketing of finished products. Indeed, the most 
important livestock agro-based commodities are the hides and skins as a derivative of the important livestock sector in Africa.

On processing of the hides and skins the transformative material becomes semi-processed leather (e.g. wet-blue) or finished leather that can be used in the manufacturing of Footwear and Leathergoods (Mwinyihija, 2010). The development of the leather sector, which is considered as one of the longest value chain, involves sustaining a dynamic raw material base, tanning, footwear, leather goods and marketing. The core stakeholders are livestock farmers, slaughterhouse owners/butchers, traders, tanners, footwear and leather goods strata.

The leather industry in Kenya had 19 tanneries with a capital investment worth Kshs. 3.8 billion (equivalent to US\$ 47.5million at 2012/13 exchange rates), employed 4,000 people and operated at an average capacity utilization of $80 \%$. However a significant decline in the leather industry was observed with the abolishment in 1990 of the $22 \%$ export compensation. This decline by 2004/2005 resulted to 10 tanneries operating at an average of $30 \%$ capacity utilization. According to the Economic survey (2010) report of Kenya, the quantum manufacturing index of the leather industry continued to indicate a positive trend with a $1.8 \%$ economic growth realized during 2008/09 review period. However, irrespective of the positive growth the unexplored value addition opportunities are immense with a potential of translating Kenya to huge trading hub in the East African countries and Africa at large.

\subsection{Purpose of the Study}

This background informs the basis of this study to analyze of the trading regime of the leather value chain strata in Kenya. In addressing this topic, the aim of the study is to attain data and synthesize as regards the leather value chain strata in response to issues regarding trade. In addition, activities that are fathomed to be critical will be highlighted through an aggregate score card for purposes of prioritization those that primal to enhance value addition and ultimate increase to trade.

\subsection{Research Question and Hypothesis}

$R 1_{a}$ : Is there a statistically significant difference between value chains and trade as measured in the leather sector strata in Kenya?

$H ~ l a_{o}$ : There is not a statistically significant difference between value chains and trade as measured in the leather sector strata in Kenya.

$H \quad l a_{a}$ : There is a statistically significant difference between value chains and trade as measured in the leather sector strata in Kenya.

\subsubsection{Contribution of Study}

The study is envisaged to contribute immensely in filling up the knowledge gap associated with trade as a panacea towards value addition within the leather sector in Africa. Most studies carryout commodity improvement without analyzing the dynamics at individual stratums to comprehend the intricacies that hinder growth and product development. In the 
proposed study each stratum will be measured against trade related activities to provide indepth analysis and further prioritize through aggregate scores aspects that can drive the value creation process. Thusly, the study will for the first time inculcate this knowledge directly to the leather sector.

\section{Methodology}

\subsection{Sample Size}

The sample size was based on an estimated population of 1,031 registered leather value chain players drawn from the Kenya leather sector. The sample size composition ensured incorporation of randomly selected players from each of the phases or stratum of the value chain. The sample size was determined through Sigma XL Version 6.2 (2013), which provided a target of 281 respondents. The statistical power analysis using this sample size indicated a value of $\alpha=0.05$ (where $\mathrm{H}_{\mathrm{O}} ; \mathrm{P}_{\mathrm{O}}=0.5$ and $\mathrm{Ha} \neq 0.5$ ), Power $(1$-Beta) $=0.922$. This was corroborated with an online a-priori sample calculator, an analytical tool by Soper (2013). Triola (2009) earlier indicated that in a quantitative study, a minimum of 30 could provide a normal distribution for a parametric analysis.

\subsection{Sampling Procedures}

The study adopted a random sampling strategy for all respondents but ensured that all the strata in the value chain were incorporated. The minimum number of respondents from each stratum was targeted. Due to the complexity of the leather value chain (Viju, 2008), such as the distances involved and remoteness of the localities in the study, internet-based survey was viewed most suitable but unfeasible due to the poor infrastructural support for internet usage as a tool. Thusly, irrespective of the convenience of electronic surveys, face to face survey was preferred due to conduct the research.

\subsection{Data Collection Methodology}

The survey was conducted using structured questionnaires. Invitations to participate in the survey were notified through emails, telephone calls, and surface mails depending on the communication method with the greatest ease of accessibility and also the researcher's established relationships with the participant

\subsubsection{Statistical Techniques}

The data analysis included descriptive statistics, calculated to describe the sample. Due to the large sample size ANOVA and pairwise set of means rather than $t$-test was performed on the mean responses of the respondents to determine if there were differences between the groups within the various levels (pre-, peri- and post-slaughter) and value chain stages (producers, butchers, hides and skins traders, tanners, footwear and leather-goods manufactures).

The statistical technique adopted a stratified random sampling approach to adequately analyze the distinct groupings in the leather value chain and their inter-relationship. The rationale for this choice was based on the different strata of the leather chain (e.g. producers, 
traders, tanners, and manufacturers of leather-goods), wherein the individual role and relationship with each other was evaluated.

Keller and Warrack (1999) indicated that the identified difference would be attributed to the divergence among the groups which is also applicable to the leather value chain. Furthermore, a correlation coefficient was used to determine if correlations exist between value addition opportunities and the identified outcome (trade). By using ANOVA and the means matrix to carryout multiple comparisons to test $\mathrm{H}_{\mathrm{O}}=\mu 1=\mu 2=\mu 3 \ldots . . \mathrm{K} ; \mathrm{H}_{\mathrm{a}}$ : at least one pairwise set of means are not equal at $\mathrm{p}<0.05$. Pursuance of data analysis due to the assumption of equal variance when using ANOVA included test of medians (Kuskal-Wallis test) and normality (Levene's test which is robust on multiple group comparison to ascertain normality). In case of unequal variances in the response data Welch's ANOVA was used. The basis overall was to determine if there were differences between the stratum within the various levels (pre-, periand post slaughter) and value chain stages (producers, butchers, hides and skins traders, tanners, footwear and leather-goods manufactures ) by derived confidence limits and $p$-value for null hypothesis $\mathrm{H}_{\mathrm{O}}: p=p o$. In this study, using ANOVA and obtaining the coefficient of determination and pairwise probabilities allowed for quantification of data and to appropriately generalize the results obtained from the population (Loslever, Cauffriez, Caouder, Turgis, \& Copin, 2012).

In addition, aggregated score on weighted total frequency score for each thematic activity in each stratum was analyzed. The purpose of using this technique was to weigh the frequency according to the participant's responses in each of the activity in a stratum (e.g. Producer, Butcher etc.) leading to the four mentioned themes (Trade, Productivity, Competitiveness and Innovation). The rationale was that the participant's response on an activity in a thematic area over another determined the relationship between value addition opportunities as measured in the leather strata in relation to the value chain. An aggregated score and a mean for each activity per stratum were computed to facilitate their ranking. The aggregated score for each parameter or activity was calculated by multiplying the total number of frequencies of each option by its respective value assigned in the various scale of the survey question.

\subsubsection{Descriptive Statistics}

The study used descriptive statistics to summarize the sample's measures of central tendencies (i.e. means, etc.) and variability (i.e. standard deviations) to determine whether the data sets would exhibit deviations (positive or negative).

\subsubsection{Correlational Analysis and Statistical Package}

This study used correlation studies (coefficient of determination $\left(\mathrm{R}^{2}\right)$ to deduce or explain on strata's variation in relation to the identified independent variable. However, while correlation analysis demonstrated the strength of the relationship between the variables, it is important to characterize the nature of the relationship (Nikolić, Muresan, Feng, \& Singer, 2012). Therefore, during the study, coefficient of determination $\left(\mathrm{R}^{2}\right)$ provided a measure of strength of the relationship between independent and dependent variables and $p$-value for null 
hypothesis $\mathrm{H}_{\mathrm{O}}: p=p o$. To evaluate the coefficient of determination analytical tools from Sigma XL (version $6.2 ; 2013$ ) was used. The advantage of this tool was its ability to identify the sub-issues (related to the research objectives stated earlier) of the study that significantly affected value addition and Trade in the leather sector.

\section{Analysis and Presentation of Results}

The pilot study had 11 sections with a total of 111 assessed items within the instrument and attained a Cronbach alpha of 0.869 . The survey instruments had a mixture of dichotomous and multi-point scales as such there was relatively heterogeneous variances in which case the use of standardized variables was appropriate (Santos, 1999; Falk \& Savalei, 2011). The attained value of 0.869 in this study was ideal value (where Cronbach alpha values between $0.7-0.95$ were considered acceptable with values above 0.80 mostly preferred) limits for ascertaining internal consistency and homogeneity (Dunn, Baguley \& Brunsden, 2013; Tavakol \& Reg, 2011).

Out of the targeted 281 respondents to be interviewed, the study yielded 244 valid responses providing a response rate of $87 \%$. The demographics of the sample included number of respondents in the identified strata in the value chain map along with gender involvement and comparisons. Age, position level, type of organization, education level and type of specialization depicted the diversity and characterization of the core value players of the leather value chain. Moreover, experience provided an insight to the conformity of the experimental prerequisite (of respondents having equal or more than 5 years exposure to the leather sector) and ultimately ascertain the reliability of responses emanating from the value chain players.

This an attempt to articulate the Trade aspects of this study, the leather chain strata (i.e. Producers, Butchers, Traders, Tanners, Leathergoods and Footwear) responses were analyzed to comprehend the sectors performance in Kenya.

\subsection{Trade}

The responses on the issue of trade as measured in the leather sector strata in Kenya are summarized in Table 1. The total number and percentage of responses related to the value chain strata on identified activities to trade opportunities are elucidated herein.

\subsubsection{Export Trade}

The results illustrated that $90 \%$ of the producers were not engaged with exports and were most probably impacted with the 80\% export tax in 2013 (reviewed upwards from $40 \%$ since 2011) through a Government directive to improve on value addition of the leather sector. In retrospect, the highest strata to be engaged with exports were the tanners $(71.4 \%)$ who apparently due to the taxation on export of hides and skins had more availed raw material for processing. To the contrary of the Tanner's experience, Leather goods $(64.7 \%)$ and Footwear $(92.3 \%)$ demonstrated the highest negation percentage to exports. The two stratum alluded to the unavailability of finished materials for their production, as most tanneries in Kenya carry 
out semi processed leather as the final product.

Further analysis indicated that ratios of export to sales on overall was low $(37.5 \%)$ on the leather strata value chain. The only registered meaningful participation registered was from the tanners $(40 \%)$ at both $11-25 \%$ and $26-50 \%$ export categories. This was an important observation that indicated the magnitude of unexplored opportunities within the leather value strata for other stratums that influenced the low results apart from the tanners. In addition to export sales, growth was also evaluated to affirm on trade dynamism of the leather strata. The related results of growth in exports similarly, depicted that only Tanners (60\%) had registered growth of $11-25 \%$ with other stratums continuing to display lower growths.

As a follow up of other related activities to Trade, responses towards competiveness become an important aspect. The overall Leather value strata (57.8\%) indicated they had no competitive advantage (e.g. cost of production, technology, quality of their products/services etc.) in their enterprises. Yet, when technology was to be considered a precursor to competitiveness the only stratum that positively identified to this aspect were the Tanners $(60 \%)$.

When the survey results were further examined, general lack of awareness to the competitive advantage becomes conspicuous through low (22\%) responses by the strata. This observation projected a major weakness in the conceptualization of the value addition and its related accruals to the respondents. Irrespective of that observation, the preparedness of future trading in the enterprises on overall for the leather strata $(60.3 \%)$ was positive and this was associated with intense market dynamics prevailing in the sector.

Table 1. Number and percentage of response related to value chain strata on identified activities to trade opportunities (All respondents)

\begin{tabular}{|c|c|c|c|c|c|c|c|c|}
\hline \multirow{2}{*}{\multicolumn{2}{|c|}{ Activities }} & \multicolumn{6}{|c|}{ Value Chain Strata } & \multirow{2}{*}{ Total } \\
\hline & & Producer & $\begin{array}{l}\text { Butcher/ } \\
\text { Slaughter-house }\end{array}$ & & & Leather & & \\
\hline \multirow{2}{*}{$\begin{array}{l}\text { Engaged to } \\
\text { Exports } \\
\text { Trade } \\
\end{array}$} & Yes & $2(2.17 \%)$ & $0(0 \%)$ & $2(2.86 \%)$ & $5(71.43 \%)$ & $6(35.29 \%)$ & $1(7.69 \%)$ & $16(6.75 \%)$ \\
\hline & No & $90(97.83 \%)$ & $37(100 \%)$ & $68(97.14 \%)$ & $2(28.57 \%)$ & $11(64.71 \%)$ & $12(92.31 \%)$ & $221(93.25 \%)$ \\
\hline \multirow{4}{*}{$\begin{array}{l}\text { Ratio of } \\
\text { Exports to } \\
\text { Sales }\end{array}$} & $1-10 \%$ & $0(0 \%)$ & $0(0 \%)$ & $2(66.67 \%)$ & $1(20 \%)$ & $3(50 \%)$ & $0(0 \%)$ & $6(37.5 \%)$ \\
\hline & $11-25 \%$ & $0(0 \%)$ & $0(0 \%)$ & $0(0 \%)$ & $2(40 \%)$ & $1(16.67 \%)$ & $0(0 \%)$ & $3(18.75 \%)$ \\
\hline & $26-50 \%$ & $0(0 \%)$ & $0(0 \%)$ & $1(33.33 \%)$ & $2(40 \%)$ & $2(33.33 \%)$ & $1(100 \%)$ & $6(37.5 \%)$ \\
\hline & $\begin{array}{l}51 \% \text { and } \\
\text { above }\end{array}$ & $1(100 \%)$ & $0(0 \%)$ & $0(0 \%)$ & $0(0 \%)$ & $0(0 \%)$ & $0(0 \%)$ & $1(6.25 \%)$ \\
\hline \multirow{3}{*}{$\begin{array}{l}\text { Growth of } \\
\text { Exports }\end{array}$} & None $(0 \%)$ & $0(0 \%)$ & $6(85.71 \%)$ & $4(66.67 \%)$ & $1(20 \%)$ & $8(72.73 \%)$ & $2(66.67 \%)$ & $21(63.64 \%)$ \\
\hline & $1-10 \%$ & $1(100 \%)$ & $1(14.29 \%)$ & $2(33.33 \%)$ & $1(20 \%)$ & $0(0 \%)$ & $1(33.33 \%)$ & $6(18.18 \%)$ \\
\hline & $11-25 \%$ & $0(0 \%)$ & $0(0 \%)$ & $0(0 \%)$ & $3(60 \%)$ & $3(27.27 \%)$ & $0(0 \%)$ & $6(18.18 \%)$ \\
\hline
\end{tabular}




\begin{tabular}{|c|c|c|c|c|c|c|c|c|}
\hline \multirow{5}{*}{$\begin{array}{l}\text { Identified } \\
\text { Competitive } \\
\text { advantage }\end{array}$} & $\begin{array}{l}\text { I do not } \\
\text { know }\end{array}$ & $0(0 \%)$ & $8(100 \%)$ & $7(77.78 \%)$ & $0(0 \%)$ & $4(36.36 \%)$ & $3(60 \%)$ & $22(57.89 \%)$ \\
\hline & $\begin{array}{l}\text { Cost of } \\
\text { Production }\end{array}$ & $0(0 \%)$ & $0(0 \%)$ & $1(11.11 \%)$ & $0(0 \%)$ & $3(27.27 \%)$ & $1(20 \%)$ & $5(13.16 \%)$ \\
\hline & Technology & $0(0 \%)$ & $0(0 \%)$ & $0(0 \%)$ & $3(60 \%)$ & $0(0 \%)$ & $0(0 \%)$ & $3(7.89 \%)$ \\
\hline & $\begin{array}{l}\text { Quality of } \\
\text { Product }\end{array}$ & $0(0 \%)$ & $0(0 \%)$ & $1(11.11 \%)$ & $0(0 \%)$ & $2(18.18 \%)$ & $0(0 \%)$ & $3(7.89 \%)$ \\
\hline & $\begin{array}{ll}\text { All for } & \text { for } \\
2,3,4 & \\
\end{array}$ & $0(0 \%)$ & $0(0 \%)$ & $0(0 \%)$ & $2(40 \%)$ & $2(18.18 \%)$ & $1(20 \%)$ & $5(13.16 \%)$ \\
\hline \multirow{2}{*}{$\begin{array}{l}\text { Future } \\
\text { Trading } \\
\text { Plans in } \\
\text { Place } \\
\end{array}$} & Yes & $26(29.55 \%)$ & $23(74.19 \%)$ & $36(87.8 \%)$ & $5(83.33 \%)$ & $16(100 \%)$ & $11(100 \%)$ & $117(60.31 \%)$ \\
\hline & No & $62(70.45 \%)$ & $8(25.81 \%)$ & $5(12.2 \%)$ & $1(16.67 \%)$ & $0(0 \%)$ & $0(0 \%)$ & $77(39.69 \%)$ \\
\hline \multirow{2}{*}{$\begin{array}{l}\text { Engagement } \\
\text { in domestic } \\
\text { trade }\end{array}$} & Yes & $90(97.83 \%)$ & $36(90 \%)$ & $44(65.67 \%)$ & $6(85.71 \%)$ & $17(94.44 \%)$ & $14(100 \%)$ & $208(87.03 \%)$ \\
\hline & No & $2(2.17 \%)$ & $4(10 \%)$ & $23(34.33 \%)$ & $1(14.29 \%)$ & $1(5.56 \%)$ & $0(0 \%)$ & $31(12.97 \%)$ \\
\hline \multirow{4}{*}{$\begin{array}{l}\text { Market } \\
\text { share of } \\
\text { products }\end{array}$} & $1-10 \%$ & $14(27.45 \%)$ & $9(27.27 \%)$ & $31(68.89 \%)$ & $2(33.33 \%)$ & $10(55.56 \%)$ & $10(71.43 \%)$ & $77(45.83 \%)$ \\
\hline & $11-25 \%$ & $10(19.61 \%)$ & $17(51.52 \%)$ & $9(20 \%)$ & $2(33.33 \%)$ & $5(27.78 \%)$ & $2(14.29 \%)$ & $45(26.79 \%)$ \\
\hline & $26-50 \%$ & $16(31.37 \%)$ & $6(18.18 \%)$ & $4(8.89 \%)$ & $2(33.33 \%)$ & $2(11.11 \%)$ & $2(14.29 \%)$ & $32(19.05 \%)$ \\
\hline & $\begin{array}{l}51 \% \text { and } \\
\text { above }\end{array}$ & $11(21.57 \%)$ & $1(3.03 \%)$ & $1(2.22 \%)$ & $0(0 \%)$ & $1(5.56 \%)$ & $0(0 \%)$ & $14(8.33 \%)$ \\
\hline \multirow{5}{*}{$\begin{array}{l}\text { Growth in } \\
\text { domestic } \\
\text { Trade }\end{array}$} & None & $0(0 \%)$ & $4(11.11 \%)$ & $21(43.75 \%)$ & $0(0 \%)$ & $1(5.56 \%)$ & $1(7.69 \%)$ & $28(13.27 \%)$ \\
\hline & $1-10 \%$ & $24(27.27 \%)$ & $10(27.78 \%)$ & $16(33.33 \%)$ & $5(71.43 \%)$ & $9(50 \%)$ & $4(30.77 \%)$ & $68(32.23 \%)$ \\
\hline & $11-25 \%$ & $39(44.32 \%)$ & $19(52.78 \%)$ & $6(12.5 \%)$ & $2(28.57 \%)$ & $5(27.78 \%)$ & $7(53.85 \%)$ & $78(36.97 \%)$ \\
\hline & $26-50 \%$ & $25(28.41 \%)$ & $3(8.33 \%)$ & $5(10.42 \%)$ & $0(0 \%)$ & $2(11.11 \%)$ & $1(7.69 \%)$ & $36(17.06 \%)$ \\
\hline & $\begin{array}{l}51 \% \text { and } \\
\text { above }\end{array}$ & $0(0 \%)$ & $0(0 \%)$ & $0(0 \%)$ & $0(0 \%)$ & $1(5.56 \%)$ & $0(0 \%)$ & $1(0.47 \%)$ \\
\hline \multirow{5}{*}{$\begin{array}{l}\text { Decrease in } \\
\text { Domestic } \\
\text { Trade }\end{array}$} & None & $1(2.78 \%)$ & $6(40 \%)$ & $10(52.63 \%)$ & $2(100 \%)$ & $1(20 \%)$ & $4(80 \%)$ & $25(30.12 \%)$ \\
\hline & $1-10 \%$ & $30(83.33 \%)$ & $7(46.67 \%)$ & $3(15.79 \%)$ & $0(0 \%)$ & $1(20 \%)$ & $1(20 \%)$ & $42(50.6 \%)$ \\
\hline & $11-25 \%$ & $3(8.33 \%)$ & $2(13.33 \%)$ & $4(21.05 \%)$ & $0(0 \%)$ & $2(40 \%)$ & $0(0 \%)$ & $11(13.25 \%)$ \\
\hline & $26-50 \%$ & $2(5.56 \%)$ & $0(0 \%)$ & $1(5.26 \%)$ & $0(0 \%)$ & $1(20 \%)$ & $0(0 \%)$ & $4(4.82 \%)$ \\
\hline & $\begin{array}{l}51 \% \text { and } \\
\text { above }\end{array}$ & $0(0 \%)$ & $0(0 \%)$ & $1(5.26 \%)$ & $0(0 \%)$ & $0(0 \%)$ & $0(0 \%)$ & $1(1.2 \%)$ \\
\hline \multirow{4}{*}{$\begin{array}{l}\text { Competition } \\
\text { in Domestic } \\
\text { Trade }\end{array}$} & None $(0 \%)$ & $41(45.56 \%)$ & $13(39.39 \%)$ & $1(2.17 \%)$ & $1(14.29 \%)$ & $1(5.56 \%)$ & $2(15.38 \%)$ & $59(28.37 \%)$ \\
\hline & $\begin{array}{l}\text { More } \\
\text { intense } \\
(>20 \\
\text { players })\end{array}$ & $12(13.33 \%)$ & $4(12.12 \%)$ & $19(41.3 \%)$ & $2(28.57 \%)$ & $3(16.67 \%)$ & $7(53.85 \%)$ & $48(23.08 \%)$ \\
\hline & $\begin{array}{l}\text { Medium } \\
(10-20 \\
\text { players })\end{array}$ & $26(28.89 \%)$ & $12(36.36 \%)$ & $12(26.09 \%)$ & $2(28.57 \%)$ & $10(55.56 \%)$ & $1(7.69 \%)$ & $63(30.29 \%)$ \\
\hline & $\begin{array}{l}\text { Low (1-9 } \\
\text { players) }\end{array}$ & $11(12.22 \%)$ & $4(12.12 \%)$ & $14(30.43 \%)$ & $2(28.57 \%)$ & $4(22.22 \%)$ & $3(23.08 \%)$ & $38(18.27 \%)$ \\
\hline
\end{tabular}




\begin{tabular}{|c|c|c|c|c|c|c|c|c|}
\hline \multirow{2}{*}{$\begin{array}{l}\text { Engagements } \\
\text { in imports }\end{array}$} & Yes & $42(46.67 \%)$ & $12(36.36 \%)$ & $1(1.52 \%)$ & $4(57.14 \%)$ & $1(5.88 \%)$ & $3(23.08 \%)$ & $63(27.75 \%)$ \\
\hline & No & $48(53.33 \%)$ & $21(63.64 \%)$ & $65(98.48 \%)$ & $3(42.86 \%)$ & $16(94.12 \%)$ & $10(76.92 \%)$ & $164(72.25 \%)$ \\
\hline \multirow{3}{*}{$\begin{array}{l}\text { Ratio of } \\
\text { Imports to } \\
\text { total sales }\end{array}$} & $1-10 \%$ & $13(28.26 \%)$ & $1(7.69 \%)$ & $2(100 \%)$ & $3(75 \%)$ & $1(100 \%)$ & $2(66.67 \%)$ & $22(31.88 \%)$ \\
\hline & $11-25 \%$ & $19(41.3 \%)$ & $4(30.77 \%)$ & $0(0 \%)$ & $1(25 \%)$ & $0(0 \%)$ & $1(33.33 \%)$ & $25(36.23 \%)$ \\
\hline & $26-50 \%$ & $14(30.43 \%)$ & $8(61.54 \%)$ & $0(0 \%)$ & $0(0 \%)$ & $0(0 \%)$ & $0(0 \%)$ & $22(31.88 \%)$ \\
\hline \multirow{4}{*}{$\begin{array}{l}\text { Level of } \\
\text { import of } \\
\text { inputs }\end{array}$} & $1-10 \%$ & $17(37.78 \%)$ & $1(7.69 \%)$ & & $0(0 \%)$ & $2(100 \%)$ & $2(50 \%)$ & $22(32.35 \%)$ \\
\hline & $11-25 \%$ & $17(37.78 \%)$ & $12(92.31 \%)$ & & $0(0 \%)$ & $0(0 \%)$ & $1(25 \%)$ & $30(44.12 \%)$ \\
\hline & $26-50 \%$ & $0(0 \%)$ & $0(0 \%)$ & & $4(100 \%)$ & $0(0 \%)$ & $1(25 \%)$ & $5(7.35 \%)$ \\
\hline & $\begin{array}{l}51 \% \text { and } \\
\text { above }\end{array}$ & $11(24.44 \%)$ & $0(0 \%)$ & & $0(0 \%)$ & $0(0 \%)$ & $0(0 \%)$ & $11(16.18 \%)$ \\
\hline $\begin{array}{l}\text { Level of } \\
\text { input of } \\
\text { finished } \\
\text { products }\end{array}$ & $1-10 \%$ & $22(59.46 \%)$ & $13(100 \%)$ & $4(80 \%)$ & $2(50 \%)$ & $4(50 \%)$ & $3(60 \%)$ & $48(66.67 \%)$ \\
\hline
\end{tabular}

\subsubsection{Domestic Trade}

The dynamics of the market was evaluated through engagement in domestic trade and the resultant overall strata responses from the respondents $(87.03 \%)$ affirmed positively to such engagements. An analysis of the market share for the stratums indicated that Butchers $(51 \%)$ had $11-25 \%$ engagement to the domestic trade which in comparison to the other stratum was the highest. This observation was indicative and correlated to the high consumption of meat in the country. Moreover, the inability of the post slaughter stratum (traders, tanners, leather goods and footwear) not taking advantage of the high output from the Butchers is indicative of raw material loss in the supply chain. On the other hand, the leather goods and footwear had low domestic market shares (1-10\%) responded to by Leather goods (55.6\%) and Footwear (71.43\%). This observation was attributed to the surplus entry of the second hand and low quality leather products into the country.

Apart from engagement with domestic markets, growth rates of 11- $25 \%$ were observed by respondents $(37 \%)$ from the leather strata. In retrospect, Tanners $(71.43 \%)$ were the only stratum to have registered growth rates but at lower levels of 1-10\%. Contrary to the growth rates the respondents were implored to ascertain if there was any reduction of domestic trade. In response, they indicated that a reduction of between 11-25\% was experienced with Leather goods $(80 \%)$ and Footwear (40\%) stratums in the country. This experience was based on the impeding factors earlier mentioned related to 'dumping' of leather products and intense competition from imports which sufficed to impact on the domestic trade.

Competition when considered on the domestic trade in terms of number of players involved showed more intense (> 20 players) along the strata. However, specific stratums such as leather goods $(53.85 \%)$ and Footwear responded by indicating that medium level (10-20 
players) competition sufficed. Whilst on the other side the Tanners indicated experiencing no competition at all. Indeed, observed trends for the Tanners not experiencing competition in the leather sector was consolidated by the recent increase of tanneries from 12 in 2012 to 14 in 2014 in Kenya with even more prospect of having more by end of 2015.

\subsubsection{Import Trade}

The overall strata responses negated $(72.25 \%)$ active engagement on imports. However, this was in exception of the Tanners $(54.14 \%)$ who alluded to engage in importing most of their inputs. The inputs were mainly to cater for processing, effluent treatments, equipment's and servicing tools. This is a stratum that has benefited with the Kenya Government incentivizing on value addition of the leather sector by removing import taxes on tannery equipment and also imposing taxes on export of raw hides and skins ( increasing progressively from $20 \%$, $40 \%$ to the current $80 \%$ ). Thusly, analysis on overall strata on average ratio of imports to total sales was low with exception of particular imported inputs for the Tanners needs.

Tanners $(100 \%)$ indicated that they have a level of $26-50 \%$ of their inputs imported. Leather goods $(100 \%)$ had $1-10 \%$ of their imports on accessories (as inputs) towards their product development. Low ratios of imports to total sales and dependency on import of input to leather processing and product development have a bearing on the cost of production and eventually impact on the competitiveness of the leather strata.

\subsubsection{Regulatory}

Factors that were considered related to regulatory aspects and alluded to hinder quantities of imports. When these were evaluated in the leather stratums, Tanners response $(42.2 \%)$ illustrated that the magnitude of export demand for products determined what quantities and quality to import. As such, the leather strata on overall indicated that existing regulatory measures are not a barrier.

On export of leather and related products, further analysis on responses, demonstrated that only Tanners (57.78\%) as a stratum experienced constraints with export taxes and levies (e.g. Veterinary Services Development Fund (VSDF) Levy, local authorities etc.). To the contrary, Leather-goods and Footwear having exhibited more strength in the domestic market were not adversely affected by factors affecting exports of leather products. Thusly, a more in-depth analysis of each leather value chain stratum (with individual tables) will be pursued to discuss the inherent activities that impact on trade.

Table 2 displays the aggregated score, mean, standard deviation and rank order of each activity related to the Producer value chain stratum variables. In this table, the aggregated score for each activity was obtained as indicated earlier. Table 2 also illustrated that the aggregated score of 91.002 (means of 0.99) are marginally higher for engagement in domestic trade as an activity compared to the other stratum. This may suggest that Producers were more actively engaged in domestic trade, primarily focused on supplying the local butcher/slaughter-houses with livestock for supplying the meat industry. This trend ultimately 
avails the hides and skins within the peri-slaughter and post slaughter phases as the raw material to leather processing.

Table 2. Aggregated score, mean, standard deviation and ranking on identified activities to trade opportunities with producers

\begin{tabular}{|c|c|c|c|c|c|}
\hline \multirow[b]{2}{*}{ Activities } & \multicolumn{5}{|c|}{ Producer value chain stratum } \\
\hline & Number & $\begin{array}{l}\text { Aggregate } \\
\text { score }\end{array}$ & Mean & SD & Rank \\
\hline \multicolumn{6}{|l|}{ i. EXPORT TRADE } \\
\hline Engagement to trade & 92 & 49.998 & 0.51 & 0.7 & 5 \\
\hline Ratio of exports to sales $(\%)$ & 1 & 1 & 1 & 1 & 4 \\
\hline Growth of exports & 1 & 0.333 & 0.33 & 0.6 & 5 \\
\hline Identified Competitive advantage & 0 & 0 & 0 & 0 & 16 \\
\hline Future trading plans in place & 88 & 57.002 & 0.65 & 0.08 & 3 \\
\hline \multicolumn{6}{|l|}{ ii. DOMESTIC TRADE } \\
\hline Engagement in Domestic Trade & 92 & 91.002 & 0.99 & 1.4 & 1 \\
\hline Market share of product & 51 & 31.50 & 0.62 & 0.33 & 7 \\
\hline Growth in Domestic Trade & 88 & 53.0 & 0.60 & 0.62 & 4 \\
\hline Decrease in Domestic Trade & 36 & 15.60 & 0.43 & 0.7 & 13 \\
\hline Competition in Domestic Trade & 90 & 47.25 & 0.52 & 0.26 & 6 \\
\hline \multicolumn{6}{|l|}{ iii. IMPORT TRADE } \\
\hline Engagements in Imports & 90 & 66.0 & 0.73 & 0.28 & 2 \\
\hline Ratio of Imports to total sales (\%) & 46 & 31 & 0.7 & 0.34 & 8 \\
\hline Level of imports of inputs & 45 & 23.75 & 0.53 & 0.43 & 10 \\
\hline Level of input for finished product & 37 & 16.25 & 0.44 & 0.38 & 12 \\
\hline \multicolumn{6}{|l|}{ iv. REGULATORY } \\
\hline Factors hindering quality imports & 93 & 29 & 0.31 & 0.28 & 9 \\
\hline Factors affecting exports of products & 93 & 20.88 & 0.22 & 0.36 & 11 \\
\hline
\end{tabular}

Table 3 shows the aggregated score, mean, standard deviation and rank order in relation to Butchers in terms of activities that explore on opportunities towards value addition. As can be identified, the engagement in domestic trade by the Butchers had the highest score of 38 (mean of 0.95 ) when compared to other activities. However the score was lower to producers as demonstrated in Table 3 which illustrates the dynamic nature of the primary market producers operate. Unlike the Producers, engagement of future plans scored 27 (mean of 0.87) occupied second place for Butchers. This reflected on the importance of planning prerequisites in secondary and tertiary markets. The stratum clearly negated for any engagement with activities related with exports as was the bottomed ranked score (0).

Table 3. Aggregated score, mean, standard deviation and ranking on identified activities to trade opportunities with Butchers.

\begin{tabular}{|c|l|l|l|l|l|}
\hline & \multicolumn{5}{|c|}{ Butcher value chain stratum } \\
\hline Activities & Number & $\begin{array}{l}\text { Aggregate } \\
\text { score }\end{array}$ & Mean & SD & Rank \\
\hline i. EXPORT TRADE & & & & & \\
\hline Engagement to trade & 41 & 7.59 & 0.19 & 0.26 & 10 \\
\hline Ratio of exports to sales (\%) & 0 & 0 & 0 & 0 & 16 \\
\hline Growth of exports & 1 & 0.33 & 0.33 & 0.46 & 14 \\
\hline Identified Competitive advantage & 1 & 0.2 & 0.2 & 0.45 & 15 \\
\hline
\end{tabular}




\begin{tabular}{|c|l|l|l|l|l|}
\hline Future trading plans in place & 31 & 27.0 & 0.87 & 0.87 & 2 \\
\hline ii. DOMESTIC TRADE & & & & & \\
\hline Engagement in Domestic Trade & 40 & 38 & 0.95 & 1.20 & 1 \\
\hline Market share of product & 33 & 16.25 & 0.49 & 0.40 & 6 \\
\hline Growth in Domestic Trade & 36 & 18.6 & 0.52 & 0.63 & 4 \\
\hline Decrease in Domestic Trade & 15 & 5.20 & 0.35 & 0.38 & 12 \\
\hline Competition in Domestic Trade & 33 & 18.25 & 0.55 & 0.37 & 5 \\
\hline iii. IMPORT TRADE & & & & & \\
\hline Engagements in Imports & 33 & 22.5 & 0.68 & 0.06 & 3 \\
\hline Ratio of Imports to total sales (\%) & 13 & 8.76 & 0.67 & 0.34 & 9 \\
\hline Level of imports of inputs & 13 & 6.25 & 0.48 & 0.91 & 11 \\
\hline Level of input for finished product & 13 & 0.42 & 0.03 & 0.07 & 13 \\
\hline iv. REGULATORY & & & & & \\
\hline Factors hindering quality imports & 41 & 11.0 & 0.27 & 0.27 & 7 \\
\hline Factors affecting exports of products & 41 & 10.13 & 0.25 & 0.29 & 8 \\
\hline
\end{tabular}

Table 4 shows the aggregated score, mean, standard deviation and rank order in relation to identified activities to trade opportunities with Traders. In this stratum which also marks the epitome to Pre and Peri-slaughter activities, illustrated through a high score of 55.50 (mean 0.83 ) of engaging mostly with domestic trade. Again with active participation in the secondary and tertiary markets future trading plans were closely the second highest score of 38.5 (mean 0.83) ranking. Dealing purely with raw materials obtained from the Butchers/Slaughter house owners, the traders at this stratum have no imports involved and as such exhibited the lowest score (0) for import related activities.

Table 4. Aggregated score, mean, standard deviation and ranking on identified activities to trade opportunities with traders.

\begin{tabular}{|c|l|l|l|l|l|}
\hline & \multicolumn{3}{|c|}{ Trader value chain stratum } \\
\hline Activities & Number & $\begin{array}{l}\text { Aggregate } \\
\text { score }\end{array}$ & Mean & SD & Rank \\
\hline i. EXPORT TRADE & & & & & \\
\hline Engagement to trade & 70 & 36.0 & 0.51 & 0.65 & 3 \\
\hline Ratio of exports to sales (\%) & 3 & 1.25 & 0.45 & 0.5 & 14 \\
\hline Growth of exports & 1 & 0.44 & 0.44 & 0.38 & 15 \\
\hline Identified Competitive advantage & 9 & 2.60 & 0.29 & 0.33 & 17 \\
\hline Future trading plans in place & 41 & 38.5 & 0.94 & 1.16 & 2 \\
\hline ii. DOMESTIC TRADE & & & & & \\
\hline Engagement in Domestic Trade & 67 & 55.50 & 0.83 & 0.69 & 1 \\
\hline Market share of product & 45 & 16.25 & 0.36 & 0.25 & 8 \\
\hline Growth in Domestic Trade & 48 & 18.20 & 0.38 & 0.24 & 7 \\
\hline Decrease in Domestic Trade & 19 & 7.40 & 0.39 & 0.18 & 10 \\
\hline Competition in Domestic Trade & 46 & 22.83 & 0.50 & 0.33 & 5 \\
\hline iii. IMPORT TRADE & & & & & \\
\hline Engagements in Imports & 66 & 33.50 & 0.51 & 0.68 & 4 \\
\hline Ratio of Imports to total sales (\%) & 2 & 1.83 & 0.91 & 0.09 & 13 \\
\hline Level of imports of inputs & 0 & 0 & 0 & 0 & 16 \\
\hline Level of input for finished product & 5 & 1.86 & 0.37 & 0.44 & 12 \\
\hline iv. REGULATORY & & & & & \\
\hline Factors hindering quality imports & 71 & 21.17 & 0.30 & 0.29 & 6 \\
\hline Factors affecting exports of products & 34 & 9.90 & 0.29 & 0.41 & 9 \\
\hline
\end{tabular}


Table 5 shows the aggregated score, mean, standard deviation and ranking order related to identified activities to trade opportunities with Tanners. The ranking scores indicate that engagements to domestic trade (6.50 with mean of 0.93 ) were fundamental to Tanners. In contrast to other stratum rankings in close second place, Tanners strongly related their response to engagements to export trade with a score of 6.00 (and a mean of 0.86). As indicated earlier the Tanners end material known as wet-blue leather are semi-processed and targeted mainly to the export market. Thusly, the major domestic market activities are mostly associated with sourcing of the raw hides and skins from the Traders and Butchers. This observation may suggest that this stratum actively engages in secondary and tertiary markets in the domestic markets influencing the pricing dynamics of raw material prices and grading regimes to meet their export market targets.

Table 5. Aggregated score, mean, standard deviation and ranking on identified activities to trade opportunities with Tanners.

\begin{tabular}{|c|l|l|l|l|l|}
\hline & \multicolumn{5}{|c|}{ Tanner Value Chain Stratum } \\
\hline & Number & $\begin{array}{l}\text { Aggregate } \\
\text { score }\end{array}$ & Mean & SD & Rank \\
\hline A.tivities & & & & & \\
\hline i. EXPORT TRADE & 7 & 6.0 & 0.86 & 0.80 & 2 \\
\hline Engagement to trade & 5 & 2.75 & 0.55 & 0.55 & 11 \\
\hline Ratio of exports to sales (\%) & 5 & 4 & 0.8 & 0.9 & 5 \\
\hline Growth of exports & 5 & 3.8 & 0.76 & 1.04 & 7 \\
\hline Identified Competitive advantage & 5 & 3.8 & 0.76 & 0.08 & 6 \\
\hline Future trading plans in place & 6 & & & & \\
\hline ii. DOMESTIC TRADE & & 6.50 & 0.93 & 1.11 & 1 \\
\hline Engagement in Domestic Trade & 7 & 3.0 & 0.50 & 0.79 & 10 \\
\hline Market share of product & 6 & 3.2 & 0.46 & 0.66 & 8 \\
\hline Growth in Domestic Trade & 7 & 0.40 & 0.20 & 0.45 & 16 \\
\hline Decrease in Domestic Trade & 2 & 4.75 & 0.68 & 0.43 & 4 \\
\hline Competition in Domestic Trade & 7 & & & & \\
\hline iii. IMPORT TRADE & & 5.50 & 0.79 & 0.51 & 3 \\
\hline Engagements in Imports & 7 & 1.67 & 0.42 & 0.38 & 15 \\
\hline Ratio of Imports to total sales (\%) & 4 & 3.0 & 0.75 & 1.5 & 9 \\
\hline Level of imports of inputs & 4 & 2.0 & 0.50 & 0.71 & 14 \\
\hline Level of input for finished product & 4 & & & & \\
\hline iv. REGULATORY & & 2.50 & 0.36 & 0.48 & 12 \\
\hline Factors hindering quality imports & 7 & 2.25 & 0.32 & 0.59 & 13 \\
\hline Factors affecting exports of products & 7 & & & \\
\hline & & & & \\
\hline
\end{tabular}

Table 6 shows the aggregated score, mean, standard deviation and rank order in relation to identified activities to trade opportunities with Footwear. In this stratum, Footwear is crucial to the leather value chain, demonstrated high scores of 11 (mean 1) of engaging with future trade planning as a priority, a characteristic eminent in tertiary markets. However, closely in second ranking brings to the fore, competition in the domestic trade with a score of 9.75 (mean 0.75) as fundamental to their trading environmental. This observation collaborates earlier observations in this study where imports of second hand footwear, unavailability of finished leather from the tanning stratum, unskilled manpower and appropriate policy frame work to incentivize footwear manufacturing was highlighted. The lowest response on ratios 
of exports to sales had a score of 0.75 which was bottom ranked at position sixteen (16th) (see Table 6). This result affirmed to earlier reasons aforementioned that the Footwear stratum exhibits inability to participate and explore on the opportunities available in the export trade in Kenya.

Table 6. Aggregated score, mean, standard deviation and ranking on identified activities to trade opportunities with footwear manufacturers.

\begin{tabular}{|c|l|l|l|l|l|}
\hline & \multicolumn{3}{|c|}{ Footwear value chain stratum } \\
\hline Activities & Number & $\begin{array}{l}\text { Aggregate } \\
\text { score }\end{array}$ & Mean & SD & Rank \\
\hline i. EXPORT TRADE & & & & & \\
\hline Engagement to trade & 13 & 7.0 & 0.54 & 0.54 & 4 \\
\hline Ratio of exports to sales (\%) & 1 & 0.75 & 0.75 & 1.5 & 16 \\
\hline Growth of exports & 3 & 1 & 0.33 & 0.33 & 15 \\
\hline Identified Competitive advantage & 5 & 1.6 & 0.32 & 0.30 & 13 \\
\hline Future trading plans in place & 11 & 11 & 1 & 1.41 & 1 \\
\hline ii. DOMESTIC TRADE & & & & & \\
\hline Engagement in Domestic Trade & 14 & 1.96 & 0.14 & 0.20 & 10 \\
\hline Market share of product & 14 & 5.00 & 0.36 & 0.30 & 6 \\
\hline Growth in Domestic Trade & 13 & 6.80 & 0.52 & 0.66 & 5 \\
\hline Decrease in Domestic Trade & 5 & 1.20 & 0.24 & 0.36 & 14 \\
\hline Competition in Domestic Trade & 13 & 9.75 & 0.75 & 0.95 & 2 \\
\hline iii. IMPORT TRADE & & & & & \\
\hline Engagements in Imports & 13 & 8.00 & 0.62 & 0.22 & 3 \\
\hline Ratio of Imports to total sales (\%) & 3 & 2.022 & 0.67 & 0.35 & 9 \\
\hline Level of imports of inputs & 45 & 19.7 & 0.44 & 0.32 & 11 \\
\hline Level of input for finished product & 5 & 1.75 & 0.35 & 0.41 & 12 \\
\hline iv. REGULATORY & & & & & \\
\hline Factors hindering quality imports & 14 & 3.62 & 0.26 & 0.23 & 8 \\
\hline Factors affecting exports of products & 14 & 3.63 & 0.26 & 0.26 & 8 \\
\hline
\end{tabular}

Table 7 shows the aggregated score, mean, standard deviation and rank order in relation to identified activities to trade opportunities with Leather goods. Similarly to Footwear, Leathergoods stratum with the top score of 17.50 (mean of 0.97 ) characterizes an intense engagement with domestic trade rather than exports. Challenges within the domestic market in aspects related to competitive trading for the Leather-goods respondents, scored 12.75 (mean of 0.71 ) and was third in rankings after planning as an activity with a score of 16 (mean 1). This observation as explained earlier for the Foot wear was equally fundamental for the Leather goods stratum as it directly related to the following;-

- low quality imports,

- unavailability of finished leather from tanning stratum (which concentrates in

semi-processed leather for exports rather than finished leather for domestic markets),

- unskilled manpower, lack of exposure to global designs and appropriate policy

frame work to incentivize leather goods manufacturing. 
The lowest response (ranked $16^{\text {th }}$ ) observed for this stratum was on aspects related to imports of inputs with a score of 0.50 (mean of 0.25). This illustrated insights on the reason behind the lack of finesse to the final leather goods products. This response is directly attributed to the fact that there are no 'state of the art' local leather goods accessories manufacturers in Africa. As such, importing remains the sole option for the time being. Thusly, lack of import of necessary inputs to this stratum adversely impacts on the quality of the produced products trend-wise and salability.

Table 7. Aggregated score, mean, standard deviation and ranking on identified activities to trade opportunities with leather goods manufacturers.

\begin{tabular}{|c|l|l|l|l|l|}
\hline & \multicolumn{5}{|c|}{ Leather goods value chain strata } \\
\hline Activities & Number & $\begin{array}{l}\text { Aggregate } \\
\text { score }\end{array}$ & Mean & SD & Rank \\
\hline i. EXPORT TRADE & & & & & \\
\hline Engagement to trade & 17 & 11.50 & 0.68 & 0.04 & 4 \\
\hline Ratio of exports to sales (\%) & 6 & 2.75 & 0.46 & 0.42 & 13 \\
\hline Growth of exports & 11 & 5.67 & 0.52 & 0.45 & 7 \\
\hline Identified Competitive advantage & 11 & 5.40 & 0.49 & 0.33 & 9 \\
\hline Future trading plans in place & 16 & 16 & 1 & 1.4 & 2 \\
\hline ii. DOMESTIC TRADE & & & & & \\
\hline Engagement in Domestic Trade & 18 & 17.50 & 0.97 & 1.30 & 1 \\
\hline Market share of product & 8 & 3.33 & 0.42 & 0.17 & 12 \\
\hline Growth in Domestic Trade & 18 & 9.40 & 0.52 & 0.39 & 5 \\
\hline Decrease in Domestic Trade & 5 & 2.60 & 0.52 & 0.48 & 14 \\
\hline Competition in Domestic Trade & 18 & 12.75 & 0.71 & 0.69 & 3 \\
\hline iii. IMPORT TRADE & & & & & \\
\hline Engagements in Imports & 17 & 9 & 0.53 & 0.58 & 6 \\
\hline Ratio of Imports to total sales (\%) & 17 & 5.67 & 0.33 & 0.58 & 8 \\
\hline Level of imports of inputs & 2 & 0.50 & 0.25 & 0.50 & 16 \\
\hline Level of input for finished product & 8 & 3.50 & 0.44 & 0.32 & 11 \\
\hline iv. REGULATORY & & & & & \\
\hline Factors hindering quality imports & 8 & 2.17 & 70.27 & 0.21 & 15 \\
\hline Factors affecting exports of products & 18 & 63 & 23 & 0.21 & 10 \\
\hline
\end{tabular}

Table 8 details the differences in Trade opportunities activities in the Leather strata, summary Information, ANOVA, pairwise mean differences and related probabilities $(n=96)$. The ANOVA and means matrix was used to make the computations required to run the analysis of variance and multiple comparison of the leather strata. As observed in this table, the ANOVA $p$ value of 0.000 illustrated that at least one pairwise set of means are not equal. From the means matrix the inference is that the means between Producers and Traders were significantly $(\mathrm{p}<0.05)$ different with Tanners, Footwear and Leather goods. The $\mathrm{R}^{2}$ (square) value indicated in Table 8 suggested that $36.94 \%$ of the strata's variation is explained by the identified activities in trade opportunities. 
Table 8. Trade opportunities activities in the Leather strata summary Information, ANOVA, pairwise mean differences and related probabilities $(n=96)$

\begin{tabular}{|c|c|c|c|c|c|c|}
\hline Summary Information & Producer & Butcher & Trader & Tanner & Footwear & $\begin{array}{l}\text { Leather } \\
\text { goods }\end{array}$ \\
\hline Count & 16 & 16 & 16 & 16 & 16 & 16 \\
\hline Mean & 33.348 & 11.905 & 16.702 & 3.488 & 6.992 & 5.299 \\
\hline Standard Deviation & 25.739 & 10.891 & 16.833 & 1.705 & 5.147 & 5.046 \\
\hline $\begin{array}{r}\text { UC (2-sided, 95\%, } \\
\text { pooled) }\end{array}$ & 40.132 & 18.689 & 23.486 & 10.272 & 13.776 & 12.083 \\
\hline $\begin{array}{r}\text { LC (2-sided, 95\%, } \\
\text { pooled) }\end{array}$ & 26.564 & 5.121 & 9.918 & -3.296 & 0.208143 & -1.485 \\
\hline \multicolumn{7}{|l|}{ ANOVA Table } \\
\hline Source & SS & DF & MS & $\mathbf{F}$ & p-value & \\
\hline Between & 9836.9 & 5 & 1967.4 & 10.546 & 0.0000 & \\
\hline Within & 16790 & 90 & 186.55 & & & \\
\hline Total & 26627 & 95 & & & & \\
\hline $\begin{array}{r}\text { Pooled Standard } \\
\text { Deviation = }\end{array}$ & 13.658 & & $\mathbf{R}-\mathbf{S q}=$ & $36.94 \%$ & & \\
\hline $\mathbf{D F}=$ & 90 & & $\begin{array}{l}\text { R-Sq } \\
\text { adj. }=\end{array}$ & $33.44 \%$ & & \\
\hline $\begin{array}{l}\begin{array}{l}\text { Pairwise Mean } \\
\text { (row - column) }\end{array} \\
\end{array}$ & Producer & Butcher & Trader & Tanner & Footwear & $\begin{array}{l}\text { Leather } \\
\text { goods }\end{array}$ \\
\hline Producer & 0 & 21.443 & 16.646 & 29.860 & 26.356 & 28.049 \\
\hline Butcher & & 0 & -4.797 & 8.417 & 4.913 & 6.606 \\
\hline Trader & & & d & 13.214 & 9.710 & 11.403 \\
\hline Tanner & & & & 0 & -3.504 & -1.811 \\
\hline Footwear & & & & & 0 & 1.693 \\
\hline Leather goods & & & & & & 0 \\
\hline Pairwise Probabilities & Producer & Butcher & Trader & Tanner & Footwear & $\begin{array}{l}\text { Leather } \\
\text { goods }\end{array}$ \\
\hline Producer & & 0.0000 & 0.0009 & 0.0000 & 0.0000 & 0.0000 \\
\hline Butcher & & & 0.3232 & 0.0848 & 0.3117 & 0.1747 \\
\hline Trader & & & & 0.0075 & 0.0473 & 0.0204 \\
\hline Tanner & & & & & 0.4700 & 0.7086 \\
\hline Footwear & & & & & & 0.7267 \\
\hline Leather goods & & & & & & \\
\hline
\end{tabular}

\section{Discussion of Results}

The thematic aspect of the study was related to the analysis of trade as measured in the leather sector strata in Kenya. According to Powers (2012), trade transactions related to the 
leather sector along the value chain are crucial to evaluate each stratum and with derived observations analysis of potential impact becomes feasible.

Ratios of export to sales on overall was low (37.5\%) on the leather strata with the only registered meaningful participation registered from the tanners $(40 \%)$ at both $11-25 \%$ and 26-50\%. This was an important observation that indicated the magnitude of unexplored opportunity within the leather value strata. To further affirm on this notion, evaluation of growth of exports showed that only Tanners (60\%) had registered growth of $11-25 \%$ with other strata displaying lower growths on exports. This warrants interventions or optimization to identify unexplored opportunities within the other production stratums for the purposes of agility in value addition (Swafford, Ghosh, \& Murthy, 2006).

As a follow up of other related activities to Trade, competiveness become an important aspect where the overall Leather value strata $(57.8 \%)$ inability of identifying competitive advantage (e.g. cost of production, technology, quality of their products/services etc.) of their enterprises was fundamental. Similar studies by the National Productivity Centre (NPC, 2010), India reporting on the leather sector indicated the same by further observing that the effect of raw materials prices on tanneries equally affected the other leather chain stratums, particularly the competitiveness of the leather-goods and footwear subsectors.

The general lack of awareness to the competitive advantage with the low (22\%) responses by other strata projected a major weakness in the conceptualization of the value addition and related accruals to the participants. Elliot, Ekpott, \& Sieper, (2011) attests to this observation and illustrate that lack of tangible value addition initiatives, unexploited potential opportunities attributed to a lack of awareness, and the need for appropriate policies directed towards most of the commodities in Africa, with the leather sector being no exception.

Of interest, irrespective of this observation was on overall, the leather strata $(60.3 \%)$ responded to have future trading plans and this was mostly associated with the intense market dynamics prevailing in the leather sector. Therefore, imports of crucial input forms part of this dynamism in ensuring appropriate production. Rojid (2007) suggest that intra imports can be pursued through strengthening of regional blocks in Africa to develop the national and global leather sector, eventually providing alternative pathway to improve on the continent's general economic performance in trade.

In overall the leather strata responses negated (72.25\%) to active engagement on imports. However, the exception was with Tanners $(54.14 \%)$ who alluded to engage in importing most of their inputs. It was important for the tanners as their input needs were to cater for processing, effluent treatments, equipment's and servicing tools. Indeed, this is a stratum that has benefited from the Kenya Government policy incentivizing on value addition of the leather sector. This policy related to the removal of import taxes on tannery equipment and also imposing taxes on export of raw hides and skins (increasing from 20\%, $40 \%$ to the current $80 \%$ ).

Tanners strongly related their response to engagements to export trade with a score of 6.00 
(mean of 0.86). As indicated earlier the Tanners final product known as wet-blue leather are semi-processed and targeted mainly to the export market as it has lower utility to leather goods and footwear if unfinished. Thusly, the major domestic market activities are associated with sourcing of the raw hides and skins from the Traders and Butchers. This observation may suggest that this stratum actively engages in secondary and tertiary markets in the domestic markets influencing the pricing dynamics of raw material prices and grading regimes to meet their export market targets. However, according other studies by Decreux \& Spies (2012) and Mwinyihija, (2011) the tertiary markets at the global level affects Africa's productivity as the continent attracts lower prices for its leather and leather products when prices are getting even higher at the global levels.

The leather goods and Footwear stratums which are crucial in the value chain demonstrated high scores of 11 (mean 1.41) of engaging with future trade planning. This was followed closely with the second ranking activity which indicated competition in the domestic trade (score of 9.75 and mean 0.75 ) as fundamental to their trading environmental. This collaborated earlier observation in this study where imports of second hand footwear, unavailability of finished leather from tanning stratum, unskilled manpower and appropriate policy frame work to incentivize footwear manufacturing required to optimize production at this level. In tandem to studies by Conceição, Mukherjee, \& Nayyar (2011) and Handoussa, (2009) they asserted that the inability to develop the potential of the leather sector due to some of the challenges cited, adversely impacted the alleviation of poverty, employment creation, wealth generation, gender parity, rural development, and the overall productivity of the leather sector in Africa.

Trade opportunities activities in the Leather strata summary on ANOVA, pairwise mean differences and related probabilities $(n=96)$ were significant $(p=0.000)$. This was an important result as it illustrated that there is a statistically significant difference between value chains and trade as measured in the leather sector strata in Kenya.

\section{Conclusion}

The study related the outcomes of the analysis of the trading regime of the leather value chain strata in Kenya with important deduction on aspects such as exports, domestic trade, imports and on regulatory framework. These aspects were found to vary on their impact on the different leather value chain stratums. For instance, the producers, butchers/slaughter house owners and traders who for the pre and peri-slaughter phase of the stratums were found to be more focused in domestic trade than other activities. These were phases that were not subjected to intense competition and as such were contented with their trading regimes. In retrospect, the post-slaughter phases of the leather stratum had a varied perspective to trading. The tanners had strong inclination towards both domestic and export markets. This was apparent as the tanners required raw materials from the domestic markets for their processing needs. Whilst for their semi processed materials, the tanners concentrated for the export market as the material has low utility in the domestic market unless if the material is finished as leather. For the footwear and leather goods had different trading challenges which included 
high competition emanating from second hand and poor quality leather goods and footwear. Thusly, the need for government intervention to develop policies to assist the upper tires of the value strata to facilitate their trading regimes in areas recapitalization, infrastructure and market development. This is because the existing policies favour the tanners but not the footwear and the Leathergoods sub-sectors which are crucial in the trickling down effect, employability and wealth creation.

\section{Acknowledgement}

Unreserved appreciation to Professor William Quiesenberry of SMC-University for his support and guidance, Monarch University for post-doctorate facilities, Kenya Leather Development Council staff in assisting with the survey work and Leather and Leather Products Institute staff in creating time to appraise the research work.

\section{References}

Conceição, P., Mukherjee, S., \& Nayyar, S. (2011). Impacts of the economic crisis on human development and the MDGs in Africa. African Development Review, 23(4), 439-460. http://dx.doi.org/ 10.1111/j.1467-8268.2011.00298.x.

Decreux, Y., \& Spies, J. (2012). Africa's trade potential export opportunities in growth markets. International Trade Forum, 4, 14-16.

Dunn, T. J., Baguley, T., \& Brunsden, V. (2013). From alpha to omega: A practical solution to the pervasive problem of internal consistency estimation. British Journal of Psychology. http://dx.doi.org/ 10.1111/bjop.12046.

Elliot, L. E., Ekpott, N., \& Sieper, H. (2011). Creating wealth by harnessing opportunities in Africa: GOD's way to multiply the assets in your storehouses. Charlotte, NC, Conceptualee Inc.

Falk, C. F., \& Savalei, V. (2011). The relationship between unstandardized and standardized alpha, true reliability, and the underlying measurement Model. Journal of Personality Assessment, 93(5), 445-453. http://dx.doi.org/10.1080/00223891.2011.594129

Food and Agriculture Organization of the United States (FAO). (2011). World statistical compendium for raw hides and skins, leather and leather footwear 1992 - 2011. Commodities and Trade division, Viale delle Terme di Caracalla, Rome, Italy.

Handoussa, H. (2009). Lessons from the MDGs in Africa. African Development Review, 21(2), 213-223. http://dx.doi.org/ 10.1111/j.1467-8268.2009.00208.x

Keller, G., \& Warrack, B. (1999). Statistics for management and economics. Pacific Groove, CA: Duxbury Press.

Kenya National Bureau of Statistics. (2012). Republic of Kenya economic survey for fiscal year 2012. Retrieved from http://www.knbs.or.ke 
Loslever, P. P., et al. (2012). A scale fuzzy windowing comparison applied to multivariate descriptive analysis. Intelligent Data Analysis, 16(2), 279-303. http://dx.doi.org/ 10.3233/IDA-2012-0524

Moyer-Packenham, P. S. et al. (2013). Effective choices and practices: Knowledgeable and experienced teachers' uses of manipulatives to teach mathematics. Online Journal of Education Research, 2(2), 18-33.

Mwinyihija, M., \& Quisenberry, W. (2013). Review of the challenges towards value addition of the leather sector in Africa. Global Advanced Research Journal of Management and Business. 2(11), 518-528.

Mwinyihija, M. (2014). Emerging world trends and continental shifts on leather and leather goods production. Advances in Business Management and Administration, 1(1), 01- 013.

Mwinyihija, M. (2010). Ecotoxicological diagnosis in the tanning industry. New York, NY: Springer Publisher.

Mwinyihija, M. (2011). The world footwear and perspectives for leather. Proceedings of the world leather congress: Present and future. Rio de Janeiro, Brazil: Editora Ltda, p. 34-35. [online] Available and from http://www.issuu.com/iconographic/docs/anais_do_congresso_mundial_do_couro (July, $6^{\text {th }}$ 2014)

National Productivity Center (NPC), (2010). Productivity and competitiveness of Indian manufacturing sector; Leather and Leather Products, The Final Report. Economic Services Group. New Delhi, India: Author. Retrieved from http//:www.nmcc.nic.in/pdf/leather $\left(5^{\text {th }}\right.$ July, 2014).

Nikolić D. et al. (2012). Scaled correlation analysis: a better way to compute a cross-correlogram. European Journal of Neuroscience, 35, 742-762. http://dx.doi.org/ 10.1111/j.1460-9568.2011.07987.

Powers, W. (2012). The value of value added: Measuring global engagement with gross and value-added trade." World Economics, 13(4), 19-38.

Rojid, S. (2007, March). Impact of COMESA forming a custom union-A CGE analysis. In Centre for the Study of African Economies (CSEA) Conference 2007 on Economic Development in Africa, University of Oxford.

Santos, J. R. A. (1999). Cronbach's alpha: A tool for assessing the reliability of scales. Journal of extension, 37(2), 1-5.

Sharma, K., Pathania, M. S., \& Lal, H. (2010). Value chain analysis and financial viability of agro-processing industries in Himachal Pradesh. Agricultural Economics Research Review, 23, 515-522.

Soper, D. S. (2013). A-priori sample size calculator for student T-tests [Computer software]. 


\section{Macrothink}

Retrieved from http://www.danielsoper.com/statcalc (December $20^{\text {th }}, 2013$ ).

Swafford, P. M., Ghosh, S., \& Murthy, N. N. (2006). A framework for assessing value chain agility. International Journal of Operations \& Production Management, 26(2), 118-140. http://dx.doi.org/10.1108/01443570610641639.

Tavakol, M, \& Reg, D. (2011). "Making sense of Cronbach's alpha."International Journal of Medical Education, 2, 53-55. http://dx.doi.org/10.5116/ijme.4dfb.8dfd

Triola, M. F. (2009). Elementary statistics (11th ed.). New York, NY: Addison Wesley.

Viju. M. (2008). African leather supply chain: An analysis. ICFAI Journal of Supply Chain Management, 5(3), 43-58.

\section{Copyright Disclaimer}

Copyright for this article is retained by the author(s), with first publication rights granted to the journal.

This is an open-access article distributed under the terms and conditions of the Creative Commons Attribution license (http://creativecommons.org/licenses/by/3.0/). 